\title{
Racial incidence of pseudoexfoliation of the lens capsule
}

\author{
W. E. GILLIES
}

From the Glaucoma Clinic, Royal Victorian Eye and Ear Hospital, Melbourne, Australia

The condition of pseudoexfoliation of the lens capsule seems common in some racial groups, $\frac{0}{0}$. and a high incidence of the condition has been reported in Scandinavia (Ladekarl, I965;\% Hansen and Sellevold, 1968; Klouman, I967; Thomassen, I 949; Backhaus and Lorentzen, ı 966 ; Hørven, I 966a), and in Greece (Joannides, Katsourakis, and Velissaropoulos, I 96 г ). This raises the question whether pseudoexfoliation is restricted to some racial groups or is을 common in persons of most nationalities.

Pseudoexfoliation of the lens capsule (Dvorak-Theobald, r954) is often associated $\subsetneq$ with glaucoma so that the question is of some importance. Recently the condition has ${ }_{\overrightarrow{0}}^{\circledR}$ been called fibrillopathia epitheliocapsularis (Bertelsen, 1966; Bertelsen and Ehlers, I969; Bertelsen, Drablös, and Flood, I964), and it had earlier been called exfoliation of the lens capsule (Irvine, I940, Gradle and Sugar, I947; Garrow, I938; Sobhy Bey, I 932).

In Australia a population of diverse racial origin exists as a result of extensive immigration since the second world war, and this has made it possible to compare the incidence of pseudoexfoliation in different racial groups.

\section{Material and methods}

The patients were all seen at the glaucoma clinic of the Royal Victorian Eye and Ear Hospital. Most of them were referred for investigation of glaucoma, but many were referred because of the known interest at the clinic in pseudoexfoliation

The presence of pseudoexfoliation of the lens capsule was determined by slit-lamp examination with undilated and dilated pupils, particular attention being paid to the pupil margin and anterior lens capsule.

Ocular hypertension was considered to be present if an applanation pressure greater than 22 음 $\mathrm{mm} . \mathrm{Hg}$ was recorded and verified.

The age of the patient at presentation and the country of birth were recorded as well as family history of glaucoma or any other ocular condition.

\section{Results}

There were I 39 (64 males) cases of pseudoexfoliation of the lens capsule, including 850 bilateral cases ( 38 males) and 54 unilateral cases ( 26 males).

The 85 bilateral cases comprised 53 with bilateral ocular hypertension, fourteen with unilateral ocular hypertension, and eighteen with normal tension (Table I).

The 54 unilateral cases comprised six with bilateral ocular hypertension, 34 with unilateral ocular hypertension, and I 4 with normal tension (Table I, opposite).

Of the six patients with unilateral pseudoexfoliation and bilateral ocular hypertension, four had absolute glaucoma in the eye which appeared to be free from pseudoexfoliation. 
Table I Pseudoexfoliation and hypertension

\begin{tabular}{|c|c|c|c|c|c|c|c|}
\hline \multirow{2}{*}{ Pseudoexfoliation } & \multirow{2}{*}{ Hypertension } & \multirow{2}{*}{$\begin{array}{l}\text { No. of } \\
\text { Cases }\end{array}$} & \multicolumn{2}{|l|}{ Sex } & \multirow{2}{*}{$\begin{array}{l}\text { Average age } \\
(y r s)\end{array}$} & \multicolumn{2}{|c|}{ Family History } \\
\hline & & & Male & Female & & Glaucoma & Other \\
\hline \multirow[t]{3}{*}{$\begin{array}{l}\text { Bilateral } \\
(85)\end{array}$} & Bilateral & $5^{2}$ & 28 & 24 & $\begin{array}{l}70 \\
(46-92)\end{array}$ & 5 & Io \\
\hline & Unilateral & 15 & 5 & ro & $\begin{array}{l}68 \\
(54-88)\end{array}$ & $\mathbf{I}$ & 3 \\
\hline & None & 18 & 5 & I3 & $\begin{array}{l}76 \\
(67-84)\end{array}$ & 0 & 3 \\
\hline \multirow[t]{3}{*}{$\begin{array}{l}\text { Unilateral } \\
(54)\end{array}$} & Bilateral & 6 & 2 & 40 & $\begin{array}{l}71 \\
\left(6_{5}-77\right)\end{array}$ & $\mathbf{o}$ & I \\
\hline & Unilateral & 34 & 19 & 15 & $\stackrel{70}{(50-81)}$ & o & 3 \\
\hline & None & 14 & 5 & 9 & $\begin{array}{l}68 \\
\left(5^{2}-83\right)\end{array}$ & $\mathbf{I}$ & 2 \\
\hline
\end{tabular}

The other two cases appear to be definite examples of unilateral pseudoexfolitaion with bilateral ocular hypertension.

AVERAgE AGE AT PRESENTATION

This was about 70 years in all groups, except that cases of bilateral pseudoexfoliation without glaucoma seemed to present later ( 76 years).

SEX

There was a slight preponderance of females in the whole series (75 out of 139), but an almost equal number of males (54) and females (53) developed ocular hypertension.

FAMILY HISTORY

A family history of glaucoma was present in only seven cases and in 22 cases there was a history of other serious ocular defects.

\section{THROMBOSIS OF THE GENTRAL RETINAL VEIN}

This occurred in thirteen patients in the series; ten were cases of bilateral exfoliation with bilateral ocular hypertension and three were cases of unilateral exfoliation with unilateral ocular hypertension.

Six of the ten patients with bilateral pseudoexfoliation and thrombosis of the central retinal vein developed thrombotic glaucoma.

Two of the three patients with unilateral pseudoexfoliation and thrombosis of the central retinal vein developed thrombotic glaucoma. In the third patient the thrombosis occurred in an only eye, but subsequently cleared with anticoagulants.

RAGIAL INGIDENGE (Table II, overleaf)

The condition was widespread amongst the various racial groups making up the Australian population, more or less in the expected proportions. 
Table II Comparison of birthplace pseudoexfoliation patients and normal population

\begin{tabular}{|c|c|c|c|c|}
\hline \multirow{2}{*}{\multicolumn{2}{|c|}{ Birthplace }} & \multicolumn{2}{|l|}{ Patients } & \multirow{3}{*}{$\begin{array}{l}\text { Population of Victoria } \\
\text { (From I966 census) } \\
\text { (Per cent. }) \\
79 \cdot 8\end{array}$} \\
\hline & & \multirow{2}{*}{$\frac{\text { Number }}{\text { Ior }}$} & \multirow{2}{*}{$\frac{\text { Per cent. }}{72 \cdot 7}$} & \\
\hline Australia (and N & Zealand) & & & \\
\hline Great Britain (ar & Ireland) & 12 & $8 \cdot 6$ & $7 \cdot 4$ \\
\hline Italy & & 7 & $5^{\circ} 0$ & 3.4 \\
\hline Greece & & 9 & $6 \cdot 5$ & $2 \cdot 0$ \\
\hline Malta & & $\mathbf{I}$ & 0.7 & 0.8 \\
\hline Germany & & o & o & $I \cdot I$ \\
\hline Netherlands & & o & o & $I \cdot I$ \\
\hline Poland & & I & 0.7 & 0.8 \\
\hline Yugoslavia & & o & o & $0 \cdot 8$ \\
\hline Other European & $\left.\begin{array}{ll}\text { Latvia } & 3 \\
\text { Russia } & 2\end{array}\right\}$ & 5 & $3 \cdot 6$ & $1 \cdot 7$ \\
\hline Other & $\left.\begin{array}{ll}\text { India } & 1 \\
\text { Ceylon } & 1 \\
\text { U.S.A. } & 1\end{array}\right\}$ & 3 & $2 \cdot 2$ & $2 \cdot 1$ \\
\hline
\end{tabular}

\section{Comment}

Pseudoexfoliation of the lens capsule has been reported from many different countries (Reddy, Reddy, and Satapathy, 1970; Sood, 1968; Kolker and Hetherington, 1970) and $\frac{\circ}{\otimes}$ it has been suggested that the incidence may vary with local heredity (Clements, I $968 ; \stackrel{\varrho}{\rightleftarrows}$ Roche, I968). In the present series the condition was found in many different racial groups with a frequency more or less corresponding to their proportion in the population.

The condition seemed to occur more frequently than the average in patients born in Latvia, Russia, and Greece-perhaps corresponding to the reported frequency of the con- $\frac{}{O}$ dition among the Baltic peoples and the Greeks.

The relatively few patients with a family history positive for glaucoma gives little support to the importance of heredity in the production of glaucoma associated with pseudoexfoliation. It therefore seems important to eliminate cases associated with pseudo- 0 exfoliation when considering the inheritance of chronic simple glaucoma. There was a 20 per cent. incidence of pseudoexfoliation in chronic open-angle glaucoma in a previous series in Australia (Gillies, 1962).

Bilateral pseudoexfoliation may be associated with either bilateral or unilateral ocular $N$ hypertension or with normal tension. After a time ocular hypertension may develop in N previously normotensive eyes. Similarly, unilateral pseudoexfoliation was often seen tog become bilateral in time.

Whether or not ocular hypertension develops in the presence of pseudoexfoliation probably depends upon the pre-existing state of the trabecular meshwork. In some patients even massive amounts of exfoliative material may not be associated with ocular hypertension. In others some degree of ocular hypertension may precede the deposition of exfoliative material; this may explain the cases in this series with unilateral exfoliation $\overrightarrow{\mathbb{Q}}$ and bilateral ocular hypertension. It is possible that exfoliative material may be present before it is clinically visible, and may cause some interference with trabecular function. 8 
It has been shown that exfoliative material may be deposited in the trabecular meshwork itself (Hørven, 1966b).

The occurrence of thrombosis of the central retinal vein in association with pseudoexfoliation has previously been noted. In this series thrombosis occurred only when pseudoexfoliation was associated with ocular hypertension and was not seen with pseudoexfoliation alone, which suggests that the thrombosis was related to the hypertension rather than to the exfoliation.

\section{Summary}

(I) A series of 139 cases of pseudoexfoliation of the lens capsule is presented. Of these 85 cases were bilateral ( 67 with ocular hypertension) and 54 cases unilateral (40 with ocular hypertension). There was a slight preponderance of females in the series, but an almost equal number of males and females were affected by ocular hypertension.

(2) Pseudoexfoliation occurred in all the major racial groups more or less in proportion to their ratio in the population, but it seemed somewhat commoner in Greeks and in those from the Baltic countries (Latvia and Russia).

(3) There were few cases of pseudoexfoliation and ocular hypertension with a positive family history for glaucoma. It seems important to consider patients with pseudoexfoliation separately when considering the inheritance of chronic open-angle glaucoma.

(4) Thrombosis of the central retinal vein seemed to occur frequently with pseudoexfoliation and ocular hypertension, but was not recorded in cases of pseudoexfoliation without hypertension.

\section{References}

BACKhaus, B., and LoRentzen, s. E. (1966) Acta ophthal. (Kbh.), 44, I

BERTELSEN, T. I. (1966) Ibid., 44, 737

—, DRABLös, P. A., and FLOOD, P. R. (1964) Ibid., 42, 1096

- and EHLERS, N. (1969) Ibid., 47, 476

GLEMENTS, D. B. (1968) Brit. F. Ophthal., 52, 546

DVORAK-THEOBALD, G. (1954) Amer. J. Ophthal., 37, I

Garrow, A. (1938) Brit. F. Ophthal., 22, 214

GILlIEs, W. E. (1962) Trans. ophthal. Soc. Aust., 22, 120

GRADle, H. S., and Sugar, H. s. (1947) Amer. F. Ophthal., 30, 12

hANSEN, E., and SEllevold, O. J. (1968) Acta ophthal. (Kbh.), 46, 1095

HøRVEN, I. (1966a) Arch. Ophthal. (Chicago), 76, 505

(1966b) Acta ophthal. (Kbh.), 44, 790

IRVINE, R. (1940) Arch. Ophthal. (Chicago), 23, 138

JOANNIDES, T., KATSOURAKIS, N., and Velissaropoulos, P. (196r) Ophthalmologica (Basel), r42, I6o KLOUMAN, O. F. (1967) Acta ophthal. (Kbh.), 45, 822

KOLKER, A. E., and HETHERINGTON, J. (1970) "Glaucoma with pseudoexfoliation of the lens capsule",

in "Becker and Shaffer's Diagnosis and Therapy of the Glaucomas", 3rd ed., p. 246. Mosby,

St. Louis

LADEKARL, s. (1965) Acta ophthal. (Kbh.), 43, 539

REDDY, P. S., REDDY, P. R., and SATAPATHY, M. (1970) Orient. Arch. Ophthal., 8, 143

ROCHE, J. (1968) Brit. F. Ophthal., 52, 265

SOBHY BEY, M. (1932) Ibid., 16, 65

sood, N. N. (1968) Acta ophthal. (Kbh.), 46, 2 I I

THOMASSEN, T. L. (1949) Ibid., 27, 423 